\title{
Exploring the Knowledge of Islamic Banking Among Libyan Bankers
}

\author{
Mohamed A. M. Abdelrahim El-Brassi \\ International Islamic University Malaysia, Malaysia, mohamedelbrassily@gmail.com \\ Syed Musa Alhabshi \\ International Islamic University Malaysia, Malaysia, syedmusa@iium.edu.my \\ Anwar Hasan Abdullah Othman \\ International Islamic University Malaysia, Malaysia, anwarhasan@iium.edu.my
}

Received: December 14, 2019 Revised: January 3, 2020 Accepted: January 7, 2020

\begin{abstract}
Although it has been five years since the beginning of the conversion to the Islamic banking system (IBS) in Libya., the level of knowledge of Islamic banking (IB) products and services among bankers is yet to be investigated. The study uses a quantitative research design to address the issue. A total of 207 complete and valid questionnaires were collected from bankers in several Libyan commercial banks. Statistical Package for Social Sciences SPSS version 23.0 was employed to analyze the data. Findings showed that bankers have a basic to moderate level of knowledge of IB services and products. They were unaware of some important Islamic services and products such as Musharakah, Murabahah to the purchase ordered (MPO), current Islamic account and investment banking account. The findings also concluded that the bankers were only knowledgeable about concepts of Islamic principles such as the permissibility of selling and prohibition of riba. However, they were unaware of how riba is applied in the banking system. This study urges relevant Libyan stakeholders such as government and top bank management to develop intensive Islamic banking training programs. In order to increase the level of knowledge and awareness of bankers towards IB. This would help to facilitate the conversion to (IBS) in the country.
\end{abstract}

Keywords: knowledge, Islamic banking products, employees, Libya.

JEL Classification: M10

@ IJIEF 2020 published by Universitas Muhammadiyah Yogyakarta, Indonesia All rights reserved

DOI:

https://doi.org/10.18196/ijief.2119
Web:

http://journal.umy.ac.id/index.php/ijief/article/view/7220

Citation:

El-brassi, M. A. M. A., Alhabshi, S. M., \& Othman, A. H. A. (2020). Exploring the Knowledge of Islamic Banking Among Libyan Bankers. International Journal of Islamic Economics and Finance (IJIEF), 1(2), 1-20. DOI: https://doi.org/10.18196/ijief.2119 


\section{Introduction}

The IB industry was practically unknown in the 1970s, however, since then, it has grown at a rapid pace across the world due to several reasons such as the increase of awareness among Muslims as well as non-Muslims. Knowledge of Islamic banking services and products has increased due to increased interest in IB. This interest increased particularly after the 2008 financial crisis which illustrated the strength of the Islamic banking system in comparison with the conventional banking system (CB) (HARUN, 2015). In this regard, understanding IB principles, as well as knowledge of IB among bankers, is key to the future success of Islamic banks (Wahid, 2013; Abdullah \& Rahman, 2007; Arshad, Aslam, Razi, \& Syed, 2011). Several studies have focused on this issue. According to Harun, Rashid, and Hamed (2015), there are always concerns regarding whether banking employees have adequate training and knowledge of Islamic banking.

Abdullah and Rahman (2007) stated that the majority of Islamic bankers have an inadequate understanding of the differences between Islamic and conventional banking mainly because they lack knowledge and training. As such, knowledge of IB is a critical element in IB. Libya, as a Muslim majority country, attempted to introduce IB to replace the existing conventional banking system with the enacting of Act No. 1 in 2013, which requires all financial transactions to be shariah-compliant. Various studies have concluded that there is a potential of high demand among Libyans for IB services and products due to the fact that Muslims are a majority in the country. According to Omar (2015), Libyan customers are ready and demand Islamic banking products, however, there is the question of the readiness of conventional banks and their employees to apply the new system of IB, especially in terms of their knowledge about the shari'a-compliant financial system.

On the matter of knowledge of Islamic banking among current bankers, the evidence in the literature is inconsistent. According to (Gait, 2009) and Abdulaziz (2016), Libyan banking staff have basic knowledge of IB and are aware of its products like musharakah and murabahah. However, according to Sabri Elkrghli and Abtesam Yahya (2017) and Saaid (2016), Libyan banking staff do not fully understand Islamic banking services and products.

Furthermore, El-brassi, Bello, and Alhabshi (2017) and Saaid and Shafii (2013) concluded that the lack of knowledge IB and the inadequacy of intensive training, are among the crucial issues facing the transformation process to Islamic banking in Libya. In light of this, the current study attempts to address the issue of the level of knowledge of Islamic banking among Libyan bankers.

IJIEF: International Journal of Islamic Economics and Finance, 3(1), 1-20|2 


\section{Literature Review}

\subsection{Knowledge of Islamic Banking}

There are several definitions of "knowledge," most of which are broad, with many differences based on varying operational contexts. Knowledge has been defined as "a type of instruction or recipe that sets out how an item of goods or service can be produced" (Blakeley, Lewis, \& Mills, 2005), 2005, p. 2). According to Hunt $(2003$, p. 100) knowledge is "beliefs that are true and are justified". Jaffar and Musa (2014, p. 140) defined it as "the fact or condition of knowing something with familiarity gained through experience or education,". On the other hand, awareness is defined as "having or showing realization, perception or knowledge of a situation or fact." The last definition refers to knowledge and awareness as relating to each other and is considered an essential factor in understanding behavioral intention (Omar, 2015; Jaffar \& Musa, 2014).

Regarding the IBS, knowledge, and awareness have been used to assess consumers' and bankers' understanding of IBS and related services and products. Mehtab, Zaheer, \& Ali, (2015) examined the knowledge of and the attitude toward IB among the account holders in conventional and IB and found that knowledge and practice of IB are positively related. Moreover, Harun (2015) tested the level of knowledge among bankers of IB products and reported a need to improve their level of knowledge. The study recommended that the government and stakeholders should focus on developing well-trained and skilled employees to improve the IB industry.

Tara, Irshad, Khan, and Rizwan (2014) studied the factors that influence the adoption of IB in Pakistan and concluded that awareness of Islamic finance principles is the most critical factor in the case of IB in Pakistan. Furthermore, the same study tested the role of knowledge in the intention to embrace and implement IB products and reported that the knowledge of IB was positively related to attitude and inclination to use IB products.

In Malaysia, several studies have addressed the role of knowledge in IB. Abdullah and Anderson (2015) investigated the factors affecting Islamic financial literacy among bankers in the city of Kuala Lumpur and their knowledge of IB products. They concluded that views and knowledge of IB and its products are the factors that identify the financial literacy of bank employees in Kuala Lumpur.

In other words, Wilmot (2017) revealed that Ghanaians are unwilling to adopt IB because they lack awareness and knowledge of IB and its products. In Nigeria, Kewuyemi (2015) examined customers' awareness of and attitude toward Islamic patronage banking. He reported that Nigerian Muslims and 
some non-Muslims are willing to deal with IB products and services because they are aware of such services.

Furthermore, Abdullahi and Shaharuddin (2016) studied the potential of IB in Macedonia and found that banking stakeholders are very knowledgeable and aware of IB products, which explains the high demand for IB products and services in the country. In the case of Tunisia, Aida and Imen (2014) explored the knowledge of IB products among Tunisian business students. They concluded that knowledge of IB was the most significant factor in determining the use of IB products. Also, the students expressed a desire to work in financial institutions offering IB products.

In the context of Libya, Omar (2015) examined knowledge and awareness as factors influencing the intention of customers to subscribe to the IBS. He found that knowledge and awareness of IB have a significant impact on the desire of Libyan customers to accept IB,

Regarding bankers, many studies have discussed the influence of knowledge on banking employees' behavior and practice of IBS. In Malaysia, Zainol, Shaari, and Ali (2008) stated that the majority of bankers had insufficient knowledge about IB products. In Pakistan, Arshad et al. (2011) confirmed that most Islamic banking employees have limited knowledge of IB products. Moreover, Baba and Amin (2009) mentioned that banking employees in offshore Islamic banking in Labuan, Malaysia, are confused regarding IB services and products because they have insufficient knowledge of these products and services. In contrast, Zainol et al. (2008) maintained that IB bankers are more knowledgeable than their counterparts in conventional banks that offer IB products and services through their branches and windows system. Ahmad, Palil, Abu Bakar, and Dolah (2015) concluded that the most significant factor that influences the knowledge of IB among bankers is the underlying principle that prohibits riba, gharar, and maysir. Thus, stakeholders and industry players should support training programs to increase the level of knowledge to achieve sustainable growth of IB and this is true across jurisdictions and more so in countries undergoing a transformation.

In 2013, Libya has, by virtue of law, prohibited riba and started the conversion to an Islamic banking system. Studies have mentioned the role of knowledge of Islamic banking as one of the key factors that will facilitate the transformation process to the Islamic banking system. Several studies in Libya have been done regarding the transformation to IB.

Gait (2009) investigated the attitude of Libyan consumers toward the protentional use of IB. In contrast to the findings of some other studies, he found that the majority of bank managers had a high awareness of Islamic 
finance and its products such as musharakah, bai muajjall, and Quard AL Hassan, although they were unaware of some Islamic products like mudarabah and murabahah. Sabri Elkrghli and Abtesam Yahya (2017) studied the viewpoint of Libyan bankers working in Wahda bank in the city of Benghazi regarding IB and finance and found that one of the major obstacles to the conversion process was the lack of knowledge among customers and bankers regarding IB products. There were also misunderstandings among top management about Islamic banking operations. Abdulaziz (2016) studied the opportunity of applying Islamic banking products to finance the Small and medium-sized enterprises (SMEs) in Libya using Bank Al Tanmyia as a case study. He concluded that bankers had a basic knowledge of IB concepts but had insufficient knowledge of IB products. However, this result cannot be generalized due to the study's small sample.

With regard to the conversion process to the Islamic finance system in Libya, Saaid (2016) tested the factors influencing the successful conversion to Islamic banking among bankers and concluded that IB products do exist but there is a significant lack of transformation mechanism which includes training programs.

Knowledge of bankers regarding IB products is vital in the transformation process and practice of Islamic banking. This was among the leading reasons for postponing the transformation process to Islamic banking until 2020. Moreover, most studies on the issue of knowledge of Islamic banking in Libya focused on a single bank as a case study meaning that the results cannot be generalized to the entire banking sector.

Therefore, and with reference to the majority of the literature, we can confidently say that there is a need for a certain level of knowledge to smooth the transition from conventional banking to IB in Libya especially after Law 12013 was enacted. Thus, further investigation is needed to understand and verify the actual level of knowledge of Libyan bankers concerning IB.

Based on that, this study hypothesizes that: $\mathrm{H} 1$ Libyan bankers have good knowledge of Islamic banking products and services. 


\section{Methodology}

\subsection{Sample and Procedure}

The population of this study comprises of employees working at different levels of management in Libyan commercial banks in the city of Benghazi. The sampled banks include four state-owned banks which are, Goumhoria Bank, Sahari Bank, National Commercial Bank, Al Whada Bank, these banks account for almost $90 \%$ of Libya's banking sector assets. Also, they employ the majority of bankers (CBL, 2014). The sample also included two private banks, which are ljma Al Arabi Bank, and Trade and Commerce Bank. Both accounting for around 7\% of Libyan banking sector assets, and they are considered among the most important private banks in Libya (Saaid, 2016). The sample includes a combination of different areas of specialization and scientific qualifications. Most of the targeted banks offer Islamic banking services and products through branches and Islamic windows system. The sample has been chosen of the aforementioned characteristics to increase the dependability of the results of this study. It is A non-probability sampling by selecting a judgemental sampling method. A total of 300 questionnaires was distributed, and 221 were returned. Ultimately, 207 eventually were accepted as complete and usable for analysis. According to, Shukla (2008) 200 is a threshold for an adequate sample size.

\subsection{Measurement Items}

This study adopted the quantitative method using a self-administered questionnaire for the collection of primary data. The measurement items were adapted from the literature. Section $A$ of the questionnaire concerns the demographic background of the respondents, while Section B was adapted from Wahid (2013) who surveyed the knowledge of IB among Muslim and non-Muslim consumers in Singapore and Abdullah and Rahman (2007) who surveyed the knowledge of bank managers about Islamic banking in Malaysia. These studies developed special techniques to measure a person's level of knowledge of IB products. The questionnaire is divided into three categories to assess the level of knowledge as basic, intermediate, and advanced. Out of the 13 questions, five were classified as basic, four as intermediate, and four as advanced.

The basic questions test the fundamental underpinning Shari'ah or Fiqh Muamalat concepts. These include the prohibition of riba, the concept of a loan with interest, basic differences between conventional and IB, and the respondents' awareness of IB philosophy as Muslims. 
El-Brassi, Alhabshi, \& Othman | Exploring the Knowledge of Islamic Banking Among Libyan Bankers

Table 1. Section of Categories of Islamic Banking Concepts

\begin{tabular}{|c|c|c|c|}
\hline & Questions & Difficulty & Answer \\
\hline 1 & Islam prohibits earning interest from loans. & Basic & True \\
\hline 2 & Shari'ah allows trading and sale. & Basic & True \\
\hline 3 & $\begin{array}{l}\text { IB products and services are similar to those of } \\
\text { conventional banks. }\end{array}$ & Basic & False \\
\hline 4 & Islamic banks can receive interest when they give loans. & Basic & False \\
\hline 5 & We need Islamic banking because we are Muslims. & Basic & True \\
\hline 6 & $\begin{array}{l}\text { The Islamic banking system is aimed at maximizing profit } \\
\text { only. }\end{array}$ & Intermediate & False \\
\hline 7 & $\begin{array}{l}\text { Investment in Islamic banking is based on products and } \\
\text { services that do not involve prohibited elements such as } \\
\text { gambling and alcohol. }\end{array}$ & Intermediate & True \\
\hline 8 & $\begin{array}{l}\text { Riba can be accommodated in Islamic banking if it is not } \\
\text { excessive. }\end{array}$ & Intermediate & False \\
\hline 9 & $\begin{array}{l}\text { Islamic banks can charge their customers the expenses } \\
\text { of issuing debit or Credit cards. }\end{array}$ & Intermediate & True \\
\hline 10 & $\begin{array}{l}\text { Current accounts in Islamic banking are considered as a } \\
\text { liability to the banks and hence should not be treated as } \\
\text { Qard. }\end{array}$ & Advanced & False \\
\hline 11 & $\begin{array}{l}\text { Murabaha is the sale of goods at an agreed cost-plus } \\
\text { mark-up, to be paid on spot only. }\end{array}$ & Advanced & False \\
\hline 12 & $\begin{array}{l}\text { Islam prohibits fixed or lump sum returns on } \\
\text { Mudharabah and Musharakah contracts. }\end{array}$ & Advanced & True \\
\hline 13 & $\begin{array}{l}\text { In a general mudharabah account, the mudharib may } \\
\text { invest the money in any Shari'ah-acceptable investment. }\end{array}$ & Advanced & True \\
\hline
\end{tabular}

The intermediate questions test the concept of riba and gharar, as well as the participants' extent of knowledge of IB and products. The advanced questions were developed to reflect whether the participant has an in-depth understanding of the Islamic banking system and its products.

\subsection{Data Analysis}

To analyze the data, the study used a quantitative approach by adopting SPSS and Microsoft Excel, a descriptive statistical method, and frequency distribution to describe the demographic profile of the respondents such as age, gender, level of education, as well as to test and identify the extent of knowledge among Libyan banking employees toward IB products. 


\section{Results}

\subsection{Demographic Profiles}

Table 2. Questionnaire Response Rate

\begin{tabular}{lcccc}
\hline $\begin{array}{c}\text { Questionnaires } \\
\text { Distributed }\end{array}$ & \multicolumn{2}{c}{$\begin{array}{c}\text { Questionnaires return and } \\
\text { complete }\end{array}$} & Questionnaires failed to return \\
\hline \multirow{2}{*}{300} & Numbers & Percentage & Numbers & Percentage \\
\cline { 2 - 5 } & 207 & $69 \%$ & 93 & $31 \%$ \\
\hline
\end{tabular}

This section discusses the results related to the demographic background and includes the response rate, age, job, gender, religion, and level of education. Demographic information is essential when analyzing the determinants of the level of knowledge of the respondents.

Table 2 shows that 300 questionnaires were distributed to employees of six Libyan commercial banks in Benghazi city. Out of the 300 questionnaires, 207 were returned complete (69\% of total questionnaires) while 93 (31\%) questionnaires were not returned.

The table indicates that the response rate was almost $70 \%$ of the total number of distributed questionnaires, which is considered a high response rate. According to Babbie, (1995), a response rate between $50 \%$ and $60 \%$ is considered a good response rate, while $70 \%$ is an excellent response rate. As such, the number of completed questionnaires was satisfactory and appropriate to proceed to the analysis.

Table 3. Age group of respondents

\begin{tabular}{ccc}
\hline Age & Frequency & Percentage \\
\hline Less than 26 & 9 & 4.3 \\
$26-35$ & 95 & 45.9 \\
$36-45$ & 32 & 15.5 \\
$46-55$ & 60 & 29.0 \\
More than 55 & 11 & 5.3 \\
\hline Total & 207 & 100.0 \\
\hline
\end{tabular}


Table 4. Gender Response

\begin{tabular}{|c|c|c|c|}
\hline & & Frequency & Percent \\
\hline \multirow{3}{*}{ Gender } & Male & 145 & 70.0 \\
\hline & Female & 62 & 30.0 \\
\hline & Total & 207 & 100.0 \\
\hline
\end{tabular}

Several indicators are observable in Table 3. The participants aged 26-35 years represent the biggest group, with $45.9 \%$. This is followed by those aged between 46 and 55 years (29\%), 36-45 years (15.5\%), 55 years and above (5.3\%) and less than 25 years (4.3\%). Furthermore, the table indicates that $94.7 \%$ of the participants are still actively working, while $5.3 \%$ have reached pensionable age or will do so soon.

Regarding gender, the table indicates that males outnumber female respondents by $40 \%$ which means males dominate the workforce in commercial banks in Libya.

Table 5 indicates that employees represent the largest group, with more than $50 \%$ of the sample. This is followed by the Heads of Departments with $37.25 \%$, then by managers with $6.3 \%$. On the other hand, management personnel, shariah committee members and executive managers make up only $1.9 \%$.

Table 5. Respondents' work designations

\begin{tabular}{lcc}
\hline \multicolumn{1}{c}{ Designation } & Frequency & Percentage \\
& & \\
\hline Management Personnel & 4 & 1.9 \\
Executive Manager & 13 & 1.9 \\
Manager & 77 & 6.3 \\
Head of Dept. & 4 & 1.9 \\
Shari'ah Committee & 105 & 50.7 \\
Member & 207 & 100.0 \\
Employee &
\end{tabular}


El-Brassi, Alhabshi, \& Othman | Exploring the Knowledge of Islamic Banking Among Libyan Bankers

Table 6. Level of Education

\begin{tabular}{lcc}
\hline Level of Education & Frequency & Percentage \\
\hline No Qualification & 10 & 4.8 \\
Diploma & 50 & 24.2 \\
Bachelors & 130 & 62.8 \\
Masters & 16 & 7.7 \\
PhD & 1 & 0.5 \\
\hline Total & 207 & 100.0 \\
\hline
\end{tabular}

Table 7. Years of working experience

\begin{tabular}{lrr}
\hline \multicolumn{1}{c}{ Experience } & Frequency & Percentage \\
\hline Less than 5 & 32 & 15.5 \\
$5-10$ & 55 & 26.6 \\
$11-15$ & 43 & 20.8 \\
$16-20$ & 33 & 15.9 \\
More than 20 & 44 & 21.3 \\
\hline Total & 207 & 100.0 \\
\hline
\end{tabular}

The table indicates that the majority of respondents are educated and only $4.8 \%$ are without any educational qualification. The majority have a bachelor's degree with $62.8 \%$, followed by a diploma (24.2\%), master's degree (7.7\%) and only one respondent with a PhD.

Regarding working experience, the table shows that employees who have experienced between 5and 10 years make up 26.6\%, followed by those with more than 20 years' experience (21.3\%), and those with 11 to 15 years of experience make up $20 \%$, and 16 to 20 years' experience (15.8\%), while employees with less than 5 years' experience were the smallest group in the sample with $15 \%$. It means that banking staff has sufficient experience in banking services. 


\subsection{Testing the Level of Knowledge}

The primary purpose of this study is to establish the level of knowledge of Libyan banking employees in IB services and products after five years since the issue of Act No. 1 2013, which strictly prohibits dealing with riba (interest) in the financial system and require a transition to full-fledged Islamic finance. To achieve this target, the questions in Section B are designed as true or false answers to determine the understanding of the participants of the concept of IB services and products. The 13 questions are divided into basic, intermediate and advanced levels.

These questions seek to assess the level of knowledge about IB based on the percentage of participants who answered the questions as true or false. This study adopted five classifications for assessing the level of knowledge of the participants measured by Very Good, Good, Moderate, Poor and Very Poor. This classification was adopted by Abdullah and Rahman (2007).

This study seeks to establish the level of knowledge by gathering the scores of participants' answers. For assessment, very good was scored between 90 and 100, followed by good between 80 and 89 and moderate from 70 to 79 . Scores from 60 to 69 are considered poor, and 59 and below as very poor.

This study is the first attempt to understand the level of knowledge of Libyan banking employees regarding IB. The next table presents the finding among the participants concerning their knowledge of $\mathrm{IB}$ and its services and products.

Table 8. Knowledge level classification

\begin{tabular}{|c|c|}
\hline Percentage score & Classification \\
\hline $90-100$ & Very Good \\
\hline $80-89$ & Good \\
\hline $70-79$ & Moderate \\
\hline $60-69$ & Poor \\
\hline$>59$ & Very Poor \\
\hline
\end{tabular}


El-Brassi, Alhabshi, \& Othman | Exploring the Knowledge of Islamic Banking Among Libyan Bankers

Table 9. General findings on Knowledge of Islamic banking

\begin{tabular}{|c|c|c|c|c|}
\hline No & Statement & $\begin{array}{l}\text { Level of } \\
\text { Difficulty }\end{array}$ & Score & $\begin{array}{c}\text { Level of } \\
\text { Knowledge }\end{array}$ \\
\hline 1 & Islam prohibits earning interest from loans. & Basic & $97.10 \%$ & Very good \\
\hline 2 & Shariah allows trading and sale. & Basic & $97.58 \%$ & Very good \\
\hline 3 & $\begin{array}{l}\text { Murabaha is the sale of goods at an agreed } \\
\text { cost-plus mark-up, to be paid on the spot } \\
\text { only. }\end{array}$ & Advanced & $48.78 \%$ & Very poor \\
\hline 4 & $\begin{array}{l}\text { Investment in Islamic banking should only be } \\
\text { in products and services that do not involve } \\
\text { prohibited elements such as gambling and } \\
\text { alcohol. }\end{array}$ & Intermediate & $88.11 \%$ & good \\
\hline 5 & $\begin{array}{l}\text { Islamic banks can charge their customers the } \\
\text { expenses for issuing debit or Credit card. }\end{array}$ & intermediate & $69.1 \%$ & poor \\
\hline 6 & $\begin{array}{l}\text { Islam prohibits fixed, or lump sum returns on } \\
\text { Mudharabah and Musharakah contracts. }\end{array}$ & Advanced & $68.6 \%$ & poor \\
\hline 7 & $\begin{array}{l}\text { Islamic banks can receive interest when they } \\
\text { give loans. }\end{array}$ & Basic & $70 \%$ & moderate \\
\hline 8 & $\begin{array}{l}\text { We need Islamic banking because we are } \\
\text { Muslims. }\end{array}$ & Basic & $89.4 \%$ & good \\
\hline 9 & $\begin{array}{l}\text { The Islamic banking system is aimed at } \\
\text { maximizing profit only. }\end{array}$ & Intermediate & 69.1 & poor \\
\hline 10 & $\begin{array}{l}\text { Riba can be accommodated in Islamic } \\
\text { banking if it is not excessive. }\end{array}$ & Intermediate & $78.3 \%$ & moderate \\
\hline 11 & $\begin{array}{l}\text { Current accounts in Islamic banking are } \\
\text { considered as a liability to the banks and } \\
\text { hence should not be treated as Qard. }\end{array}$ & Advanced & $27.5 \%$ & Very poor \\
\hline 12 & $\begin{array}{l}\text { The products and services of Islamic banks } \\
\text { and conventional banks are similar. }\end{array}$ & Basic & $72.9 \%$ & Moderate \\
\hline 13 & $\begin{array}{l}\text { In a general mudharabah account, the } \\
\text { mudharib may invest the money in any } \\
\text { Shari'ah-compliant investment. }\end{array}$ & Advanced & 16.4 & Very poor \\
\hline & Mean & & 70.73 & Moderate \\
\hline
\end{tabular}

Table 9 shows the results and the percentages of the correct answers. In this regard, S1 and S2 score the highest at $97.10 \%$ and $97.58 \%$ respectively. S8 scores $89.4 \%$, indicating that the participants realize the importance of the Islamic banking system as part of compliance with the Shari'ah and obedience to Allah. On the other hand, S7 and S9 are confused about the concept of riba and they score moderately $70 \%$ and $78 \%$ respectively. 
The intermediate level questions indicate high scores of correct answers especially in $\mathbf{8 8}$ with more than $88 \%$, which is "Investment in Islamic banking is based on products and services that do not involve prohibited elements such as gambling and alcohol." It reflects the strong understanding of respondents about other prohibited elements from the view of the Shari'ah such as alcohol and gambling. In contrast, the result in S5, which is about charging fees for a Credit card is poor with $69 \%$. The respondents show a poor understanding in 59 with 69\%, which is about the principles of IB, which seeks not only to maximize the profits but also to achieve Maqasid Shari'ah such as the preservation of properties (Hifth Al mal).

The most difficult questions - the advanced questions - address the concepts of musharakah, mudarabah, Murabaha and current account practice. In this regard, the respondents showed very poor scores in all questions. For instance, S13 concerning mudarabh score very poorly as only $16.4 \%$ seem to understand the concept of mudrabah and how it is practiced in Islamic banking. The majority of respondents are ignorant about the characteristics of the current account in Islamic banking, and only $27 \%$ seem to understand how the current account is used in Islamic banking. Despite practicing the Murabaha in most Libyan commercial banks since 2010, S3 shows that only $48 \%$ of the respondents understand the concept of Murabaha, which is considered a surprising result in the case of Libya.

Table 10: Sample's knowledge level

\begin{tabular}{|c|c|c|}
\hline Classification of knowledge & Mean scores & Categories \\
\hline Basic & 85.41 & Good \\
\hline Intermediate & 75.96 & Moderate \\
\hline Advanced & 40.33 & Very poor \\
\hline Total Mean & 70.73 & Moderate \\
\hline
\end{tabular}

Table 10 summarizes the outcomes of this study. The outcomes indicate that the respondents have good basic knowledge about the concept of IB while they have moderate knowledge about the intermediate terms of IB and a very poor understanding of advanced terms in IB and Islamic banking products such as Murabaha and mudarabah. In conclusion, Libyan banking employees have a barely moderate level of knowledge about IB, with only a $70.73 \%$ score. 


\section{Discussion and Implications}

This study seeks to investigate and establish the level of knowledge of Libyan banking employees about IB services and products. It is a pioneering study that tests the level of knowledge of banking staff regarding IB concepts in Libya. The outcomes suggest that banking employees have a good level of knowledge about the basic principles of the Shari'ah, such as the permissibility of selling and prohibition of riba. This result is expected as Islam is the sole religion in Libya, and the majority of Libyans are knowledgeable about the basic principles of Islamic law.

However, the staff is very confused about how riba is applied in the banking system. Libyan banking employees have a low level of knowledge and awareness regarding the variances between the IBS and the conventional system.

The findings also indicate that banking employees in Libya have very poor knowledge about PLS products, which are musharakh and mudarabah. This might be because these products are seldom used in Libyan financial markets. According to El-brassi et al. (2017), more than 90\% of Islamic banking services offered by Libyan commercial banks are based on Murabaha while less than $10 \%$ of Islamic banking products are based on musharakah offered exclusively by ALGamhouria Bank. Despite offering and practicing the Murabaha products in most Libyan commercial banks, the findings show that most Libyan banking employees still lack knowledge about the Murabaha to the purchase order (MPO). This could be due to the absence of practical training programs about Islamic banking products. Furthermore, The results observed suggest that the banking employees are unaware of the concept of the current account in Islamic banking and how it is treated from the Shari'ah perspective. In the same way, the banking staff is unaware of Islamic investment banking account, as its functions as such Islamic investment tools like Islamic portfolios and investment accounts and Sukuk are not yet available in Libya.

The outcomes of this study concluded that Libyan banking staff lacks knowledge and awareness about the theory and practice of IB, especially about different products offered in this banking system. They are unaware of the variances between the IBS and conventional banking systems. There are primary factors that created this situation in the Libyan context. Managers of Libyan commercial banks have shown no interest in applying Islamic banking as they are accustomed to conventional banking. This resistance leads to the axing of the training programs on Islamic banking in most Libyan commercial banks. The majority of Libyan banking employees are unprepared to understand and deal with Islamic banking services and products (Saaid, 
2016; El-brassi et al., 2017; Shafii, Shahimi, \& Saaid, 2016a; Shafii, Shahimi, \& Saaid, 2016b; Sabri Elkrghli \& Abtesam Yahya, 2017). These studies concluded that the most prominent issues in applying the IBS in Libya are the lack of training programs, the absence of education institutions specialized in Islamic banking knowledge, and the influence of conventional banking culture which creates resistance towards adopting Islamic banking among the leaders of the Libyan banking sector. These factors prevent the Libyan banking system from transforming into full-fledged Islamic banking to adhere to the Law No. 1 of 2013. This position indicates that Libyan commercial banks are in a dilemma about how to adopt and practice Islamic banking services and products in such circumstances.

Regarding implications, the current study addressed in detail the influence of knowledge of IB on the perception of the banking staff in the context of Libya. It proved that one of the most serious problems which prevent the transformation process in Libya is the absence of banking staff who are qualified to offer and deal with IB services and products to meet the demand from Libyan consumers for Islamic banking. Libyan banking managers need to pay more attention to increasing the level of knowledge of their subordinates regarding IB, so as to benefit from the potential market opportunities which will emerge as a result of high demand for banking services that comply with Islamic law.

The managers also need to introduce and improve the intensive training programs in Islamic banking in their respective institutions. They should support awareness campaigns about the importance of Islamic banking to increase the awareness of their staff about the IBS, which is considered a promising sector in Libya.

The study will benefit the Libyan government by highlighting the role of knowledge about Islamic banking in the conversion of the financial system to a full-fledged Islamic financial system. The government should also encourage Libyan education institutions to adopt and offer Islamic finance programs. It will contribute to creating an appropriate environment for the growth and sustainable development of the Islamic finance industry in Libya.

\subsection{Limitations of the Study and future researches}

The current study had several limitations which should be noted. Firstly, the size of the study sample may be inadequate to generalize the findings to the entire financial sector in Libya. Besides the relatively small sample size, there were some difficulties during the collection of data such as unwillingness of some employees to complete the questionnaire, and some banks refusing to 
distribute the questionnaires in their branches (Ejma Al-Alrabi Bank and Trade and Commerce Bank), there were also security concerns which prevented accessibility to a wider survey area.

In light of these limitations faced by the current study, it is recommended that future research avoid these obstacles and ensure the data collected are adequate to be able to generalize the findings. Furthermore, due to limitations of time, the current study addressed the level of knowledge regarding Islamic banking among banking staff in the city of Benghazi only. Future researches should include other areas in Libya such as Tripoli and Al Bida for a comprehensive evaluation of the level of knowledge regarding IB services and products among Libyan banking employees. Future studies should also make comparisons between the different public commercial banks and private commercial banks regarding the level of knowledge of their staff of IB and its products and services. Lastly, future study should also investigate the influence of Act No. 12013 on the perceptions of Libyan banking stakeholders towards the transformation process to full-fledged Islamic banking in Libya.

\section{Conclusion and Recommendations}

The current study explored the knowledge level among Libyan banking employees regarding IB products and services by collecting data from more than 200 respondents. The descriptive analysis was utilized to identify the outcomes which showed that Libyan banking employees have just moderate knowledge of IB products and services. Furthermore, the banking staff demonstrated very poor knowledge and awareness of most IB products currently being offered such as murabahah, musharakah, and mudarabah. The current study concludes that the majority of banking staff in Libyan commercial banks are not well informed and also lack training in Islamic banking. Therefore, Libyan commercial banks may not be able to meet the requirements of Act No. 1 of 2013, which is to transform the Libyan financial system to full-fledged Islamic finance by 2020. Thus, the current study recommends that the Libyan authorities should encourage and support educational institutions like universities to offer courses on IB and finance. However, managers of Libyan commercial banks are encouraged to help create greater awareness among their subordinates on Islamic products and services and point to the importance of successfully transforming to IB in Libya. Lastly, Libyan banking and finance institutions should seek help from international experts who are qualified in IB to increase the level of knowledge of IB among bank employees. 


\section{References}

Abdulaziz, M. A. (2016). Bank Financing for Small and Medium-sized Enterprises ( SMEs ) in Libya. Retrieved from https://researchrepository.griffith.edu.au/bitstream/handle/10072/365835/Abdulsale h_2016_01Thesis.pdf?sequence=1

Abdullah, M. A., \& Anderson, A. (2015). Islamic Financial Literacy among Bankers in Kuala Lumpur. Journal of Emerging Economies and Islamic Research, 3(2), 1-16. Retrieved from www.jeeir.com

Abdullah, R. F. S., \& Rahman, R. A. (2007). Factors influencing knowledge of Islamic banking services: The case of Malaysian bank managers. International Association for Islamic Economic, 11(2), 31-54.

Abdullahi, S., \& Shaharuddin, A. (2016). Potential for Islamic Banking in Macedonia: An Empirical Evidence. Journal of Global Business and Social Entrepreneurship, 6(4), 1039-1047.

Ahmad, M., Palil, R., Abu Bakar, A., \& Dolah, N. H. (2015). Literature Review on the Knowledge of Islamic Banking Products Among Muslim Entrepreneurs. South East Asia Journal of Contemporary Business, Economics and Law, 6(3), 20-24. https://doi.org/10.1017/CBO9781107415324.004

Aida, K., \& Imen, K. (2014). Islamic Finance for Future Entrepreneurs: Exploring Tunisian Business Students' Knowledge and Potential Usage of Islamic Financing Products. Journal of Emerging Economies and Islamic Research, 2(3), 1-14.

Arshad, M., Aslam, S., Razi, A., \& Syed, A. a. (2011). a Comparative Analysis of Bankers' Perception on Islamic Banking in Pakistan. Int. J. Eco. Res, 2(August), 1-12.

Baba, R., \& Amin, H. (2009). Offshore Bankers' Perception On Islamic Banking Niche For Labun: An Analysis. International Journal of Commerce and Management, 19(4), 293-308. https://doi.org/10.1108/10569211111165316

Blakeley, N., Lewis, G., \& Mills, D. (2005). New Zealand Treasury The Economics of Knowledge: What Makes Ideas Special for Economic Growth?

Central Bank of Libya. (2014). Annual-report-Central Bank of Libya 2014. TRIPOLI.

El-brassi, M. A. M. A., Bello, N., \& Alhabshi, S. M. (2017). Libya's Transformation to an Islamic Financial System: Issues and Challenges. International Review of Management and Business Research, 6(3), 976-994.

Earl Babbie. (2012). The Practice of Social Research (13th ed.). Canada: 
Wadsworth, Cengage Learning.

Gait, A. H. A. (2009). Libyan attitudes towards Islamic methods of finance: An empirical analysis of retail consumers, business firms and banks. Griffith University.

HARUN, T. W. B. R. (2015). Products' Knowledge Among Islamic Banks'Staffs in Alor Setar, Kedah.

Harun, T. W. R., Rashid, R. A., \& Hamed, A. B. (2015). Factors Influencing Products' Knowledge of Islamic Banking Employees. Journal of Islamic Studies and Culture, 3(1), 23-33. https://doi.org/10.15640/jisc.v3n1a4

Hunt, D. P. (2003). The concept of knowledge and how to measure it. Journal of Intellectual Capital, 4(1), 100-113. https://doi.org/10.1108/14691930310455414

Kewuyemi, K. M. (2015). Customers ' Awareness, Attitude and Patronage of Islamic Banking in Nigeria. Slam and Civilisational Renewal (ICR), 6(3).

Mehtab, H., Zaheer, Z., \& Ali, S. (2015). Knowledge, Attitudes and Practices (KAP) Survey: A Case Study on Islamic Banking at Peshawar, Pakistan. FWU Journal of Social Sciences, 9(2), 1-13.

OMAR, K. M. (2015). the Moderating Effects of Government Support and Religious Obligations on the Relationship Between Service Quality, Knowledge and Awareness of Islamic Banking System and the Intention To Subscribe the System in Libya Khairi Mohamed Omar Doctor of Busines. UNIVERSITI UTARA MALAYSIA.

Saaid, A., \& Shafii, Z. (2013). The obstacles facing conversion process from conventional banks to Islamic banking: A review of literature. In In The 5th Islamic economic conference, Malaysia. (pp. 540-558).

Saaid, A. A. K. (2016). The internal obstacles of libyan conventional banks' conversion to islamic banks. Universiti Sains Islam Malaysia Nilai.

Sabri Elkrghli, \& Abtesam Yahya. (2017). Bankers' Views Towards Islamic Banking and Islamic Marketing: The Case of Libyan Main Wahda Bank in Benghazi City. Management Studies, 6(1), 37-55. https://doi.org/10.17265/2328-2185/2018.01.004

Shafii, Z., Shahimi, S., \& Saaid, A. (2016a). Obstacles and motivation behind conversion of conventional banks to Islamic banks: An overview. International Review of Management and Business Research, 5(3), 1021-1038.

Shafii, Z., Shahimi, S., \& Saaid, A. (2016b). The factors that influence the conversion process from conventional banks into Islamic banking in Libyan conventional banks: Proposing conceptual framework. International Journal of Academic Research in Management and Business, 1(2), 1-10. 
El-Brassi, Alhabshi, \& Othman | Exploring the Knowledge of Islamic Banking Among Libyan Bankers

Shukla, P. (2008). Essentials of marketing research. Essentials of Marketing Research. https://doi.org/10.1016/S1441-3582(04)70101-9

Tara, N., Irshad, M., Khan, M. R., \& Rizwan, M. (2014). Factors Influencing Adoption of Islamic Banking: A Study from Pakistan. Journal of Public Administration and Governance, 4(3), 352-367. https://doi.org/10.5296/

WAHID, N. H. B. A. (2013). A Study Of The Knowledge And Acceptance Level Of Islamic Banking Among Muslum Consumer In Singapore. International Islamic University Malaysia.

Wilmot, A. (2017). Patronage Prospects of Islamic Banking and Finance in Ghana. Ashesi University College.

Zainol, Z., Shaari, R., \& Ali, H. M. (2008). A Comparative Analysis of Bankers' Perceptions on Islamic Banking. International Journal of Business and Management, 3(4), 157-168. 
El-Brassi, Alhabshi, \& Othman | Exploring the Knowledge of Islamic Banking Among Libyan Bankers

This page is intentionally left blank 